\title{
BIOLOGICAL ACTIVITY OF GUAZUMA ULMIFOLIA LAMARK.- SYSTEMATIC REVIEW
}

Atividade biológica da Guazuma ulmifolia Lamark.- revisão sistemática

Actividad biológica de laGuazumaulmifoliaLamark.- revisión sistemática

\section{Elga Lopes da Cunha Martins ${ }^{1 *}$, Simone Santos Oliveira Barros ${ }^{2}$, Michele} Cezimbra Perim ${ }^{2}$, Klismam Marques dos Santos ${ }^{1}$, Maria Laura Martins ${ }^{1}$, Guilherme Nobre L. do Nascimento ${ }^{1}$

${ }^{1}$ Laboratory of Basic and Health Sciences (LaCiBS), Health SciencesMasters Program, Federal University of Tocantis, Brasil.

${ }^{2}$ Health Laboratories, Federal University of Tocantis, Brasil.

*Correspondence: Laboratory of Basic and HealthSciences (LaCiBS), Nutrition Course, Federal University of Tocantins, Av. NS 15, 109Norte, Palmas, Tocantins, Brasil.CEP:77.010-090.e-mail: elgauft@uft.edu.br.

Artigo recebido em 05/10/2018 aprovado em 31/05/2019 publicado em 02/10/2019.

\begin{abstract}
The Guazuma ulmifolia Lamark (Malvaceae) is a non-endemic plant, popularly known as mutamba. Its leaves and roots are used in home remedies against dysentery and diarrhea, in the treatment of prostate, as a uterine stimulant and other diseases. Due to the characteristics presented and the growing interest in this species, a systematic review was carried out on the possible pharmacological and toxicological effects of Guazuma ulmifolia Lamark. As active compounds, the articles cited the presence of flavonoids, saponins, alkaloids, tannins, phenolic compounds and steroids in different parts of the plant and extracted with different solvents. Regarding the experimental studies, no articles were found with clinical test, and only 4 in vivo studies. About the pharmacological effects we can mention activity against leishmaniasis, hypoglycemic, anti-inflammatory, anticholinesterase, anti-obesity, antiseptic, cicatrizant and anthelmintic. The registered toxicological tests were directed against lineages of cancer cells, proving effective, however, there is a need for studies to attest the safety of G. ulmifolia use by the population. Therefore, it is imperative to carry out further studies to ensure the use of this plant, to know doses and form of indication, as well as clinical studies in order to guarantee a correct therapy.
\end{abstract}

Keywords: Guazuma ulmifolia, toxicity, medicinal plants.

\section{RESUMO}

A Guazuma ulmifolia Lamark (Malvaceae) é uma planta não endêmica, popularmente conhecida por mutamba. Suas folhas e raízes são empregadas em remédios caseiros contra disenteria e diarreias, no tratamento de próstata, como estimulante uterino e outras enfermidades. Em virtude das características apresentadas e o crescente interesse por esta espécie, tanto para fins medicinais como alimentício, realizou-se uma revisão sistemática sobre os possíveis efeitos farmacológicos e toxicológicos da Guazuma ulmifolia Lamark. Como compostos ativos, os artigos citaram a presença de flavonoides, saponinas, alcaloides, taninos, compostos fenólicos e esteróides em diferentes partes da planta e extraídos com diferentes solventes. Quanto aos estudos experimentais, não foram encontrados artigos com teste clínico e, apenas 4 estudos com testes in vivo. Dos efeitos farmacológicos encontrados, pode-se citar atividade contra leishmaniose, hipoglicemiante, antiinflamatório, anticolinesterásico, antiobesidade, antisséptico, cicatrizante e anti-helmíntico. Os testes toxicológicos registrados foram direcionados contra linhagens de células cancerígenas mostrando-se efetivo, porém, há necessidade de estudos para atestar a segurança de uso de G. ulmifolia pela 
população. Logo, apesar de utilizada, é imperativa a realização de mais estudos para assegurar o uso desta planta pela população e conhecer doses e forma de indicação, além de estudos clínicos que garantam uma correta terapêutica.

Palavras-chave: Guazuma ulmifolia, toxicidade, plantas medicinais.

\section{RESUMEN}

La Guazuma ulmifolia Lamark (Malvaceae) es una planta no endémica, popularmente conocida por mutamba. Sus hojas y raíces son empleadas em remédios caseros contra disentería y diarreas, em el tratamiento de próstata, como estimulante uterino y otras enfermedades. Em virtud de las características presentadas y el creciente interés por esta especie, tanto para fines medicinales como alimenticios, se realizó una revisión sistemática sobre los posibles efectos farmacológicos y toxicológicos de la Guazuma ulmifolia Lamark. Como compuestos activos, los artículos citaron la presencia de flavonoides, saponinas, alcaloides, taninos, compuestos fenólicos y esteroides en diferentes partes de la planta y extraídos con diferentes solventes. Encuanto a los estúdios experimentales, no se encontraron artículos conprueba clínica y, sólo 4 estudios conpruebas in vivo. De los efectos farmacológicos encontrados, se puede citar actividad contra leishmaniasis, hipoglicemiante, antiinflamatorio, anticolinesterásico, antiobesidad, antiséptico, cicatrizante y antihelmíntico. Las pruebas toxicológicas registradas se dirigieron contra los linajes de las células cancerígenas que se mostraron efectivos, pero hay necesidad de estudios para certificar la seguridad de uso de G. ulmifolia por la población. Por lo tanto, a pesar de ser utilizada, es imperativa la realización de más estudios para assegurar el uso de esta planta por la población y conocerdosis y forma de indicación, además de estudios clínicos que garanticen una correcta terapéutica.

Descriptores: Guazuma ulmifolia, toxicidad, plantas medicinales.

\section{INTRODUCTION}

Vegetable products, in addition to their role as food source, clothing and housing materials, have been used in popular therapeutics as a treatment for diseases (COPETTI e GRIEBELER, 2005) from the fight against cancer to pathogenic microorganisms (CALIXTO, 2000). Studies and discoveries use knowledge about medicinal plants in search of active principles (VEIGA JR.et al., 2005), which is a promising source for the discovery of future drugs.

Many countries with significant biological diversity of resources are developing and using traditional medicinal drug solutions for disease control, providing relief of similar symptoms and obtained from allopathic medicine (HEINRICH, 2003; BANDYOPADHYAY et al., 2004).

Guazuma ulmifolia Lam. is a common species in the Brazilian cerrado, but there is also from Amazonia to Paraná, and belongs to the family Malvaceae (SOUZA e LORENZI, 2008). It is popurlaly known as "guacimo" or "mutamba" (BERENGUER et al., 2007), the property of 5 to 10 meters in height with a trunk of 30 to $50 \mathrm{~cm}$ in diameter, with a non-vertical cracked bark, with a white and grayish heart. The canopy has abundant branching with simple alternate leaves with petiole or short stem, of yellowish color. A leaf blade with dry texture (cardboard) with rounded base and apex acuminate (with sharp or long tip), with creased or toothed margin and protruding ribs on both sides, and densely pubescent (with small hairs) when young and glabrous or smooth when adults (JBRJ, 2017).

In Mexico, bark tea is used by indigenous people to facilitate delivery, relieve gastrointestinal pain, no treatment for asthma, fever, diarrhea and dysentery (CARVALHO 2007 apud GUÁZUMA, 2001). In Peru, besides the tea of the barks, as leaves are also employed, without treatment of renal and hepatic diseases, and against dysentery. In Brazil, bark tea is used as a sweat in cases of fever, cough, bronchitis, asthma, pneumonia and liver problems (CRUZ, 1995).

Phytochemical analyzes revealed a presence of alkaloids and tannins in the infusion of the husk 
(ANDRADE-CETTO e HEINRICH, 2005). Carvalho (2007) observed the presence of isoquinolic alkaloids, triterpenic saponins, tannins and starches. Faced with characteristics presented and growing interest in this species, a review of the pharmacological and toxic products of Guazuma ulmifolia Lamark was carried out.

\section{METHODOLOGY}

A systematic review search was carried out in the bases PUBMED, Science Direct, Latin American and Caribbean Literature in Health Sciences - LILACS and Google Academic in the months from August to September of 2017. As search strategies we used the descriptors: "Guazuma ulmifolia and toxicity", "Guazuma ulmifolia and ethnopharmacology", "Guazuma ulmifolia and bioactivity" and "Guazuma ulmifolia and pharmacognosy", in the Portuguese and English languages, published between the years 2010 and 2017.

The research and evaluation of the articles were carried out by two independent researchers using as inclusion criteria: i) complete articles; ii) pre-clinical studies (in vivo and in vitro) and iii) clinical trials. They were excluded books, book chapters, dissertations and theses, conference abstracts, and review articles.

The review consists of three stages: (i) electronic search in the database, (ii) selection and identification of eligible articles and (iii) extraction of data from the studies included in the review.

For the third stage, a collection instrument elaborated by the authors was used, containing the following information: plant part, type of extraction, sample, test performed, result, author and year.

\section{RESULTS AND DISCUSSION}

The search resulted in 1,379 articles that met the inclusion criteria, corresponding to 1,341 articles in the Google Scholar database, 21 articles in the PUBMED database, 10 articles in the Science Direct database, and 07 articles in the LILACS database. They were excluded after analysis of their titles, 1,132 manuscripts. Subsequently, abstracts of the remaining 247 publications were analyzed with a view to applying the inclusion and exclusion criteria, aiming at the pharmacological and toxicological effects of the plant. From these, 197 manuscripts were excluded after this stage, and in 50 articles the analysis of the entire publication was performed. At the end of the process, 22 publications were included in the study (Figure 1).

As for the type of test used in the articles studied, none were performed in humans which are the clinical tests, and the majority were pre-clinical tests in vitro (Table 1). This lack of clinical trials follows the trend of studies for the search for new drugs, where many of the probable molecules or even plant extracts do not have proven biological activity in preclinical tests, and thus they are not taken to be tested in trials clinical trials.

The synthesis and main information present in the articles chosen in this review were grouped in Table 2. From the selected studies, the bioactive compounds identified by the phytochemical analysis of G. ulmifolia were grouped according to Table 03 .

In the phytochemical evaluation, G. ulmifolia presented active components in different extracts including flavonoids, saponins, alkaloids, tannins, total phenols and steroids present in the bark, leaves, fruits and rhizome of the plant. It is suggested that the data generated can provide the basis for a wide use as a therapeutic agent (ISWANTINI et al., 2011; PELÁEZ e RODRÍGUEZ, 2016; BATUBARA et al., 2012; PATILe BIRADAR, 2013; LUNA-CAZARES, 2017), 
as a source of new molecules with pharmacological activity.

Figure 1. Flowchart of the systematic data obtained on Guazuma ulmifolia Lamark.

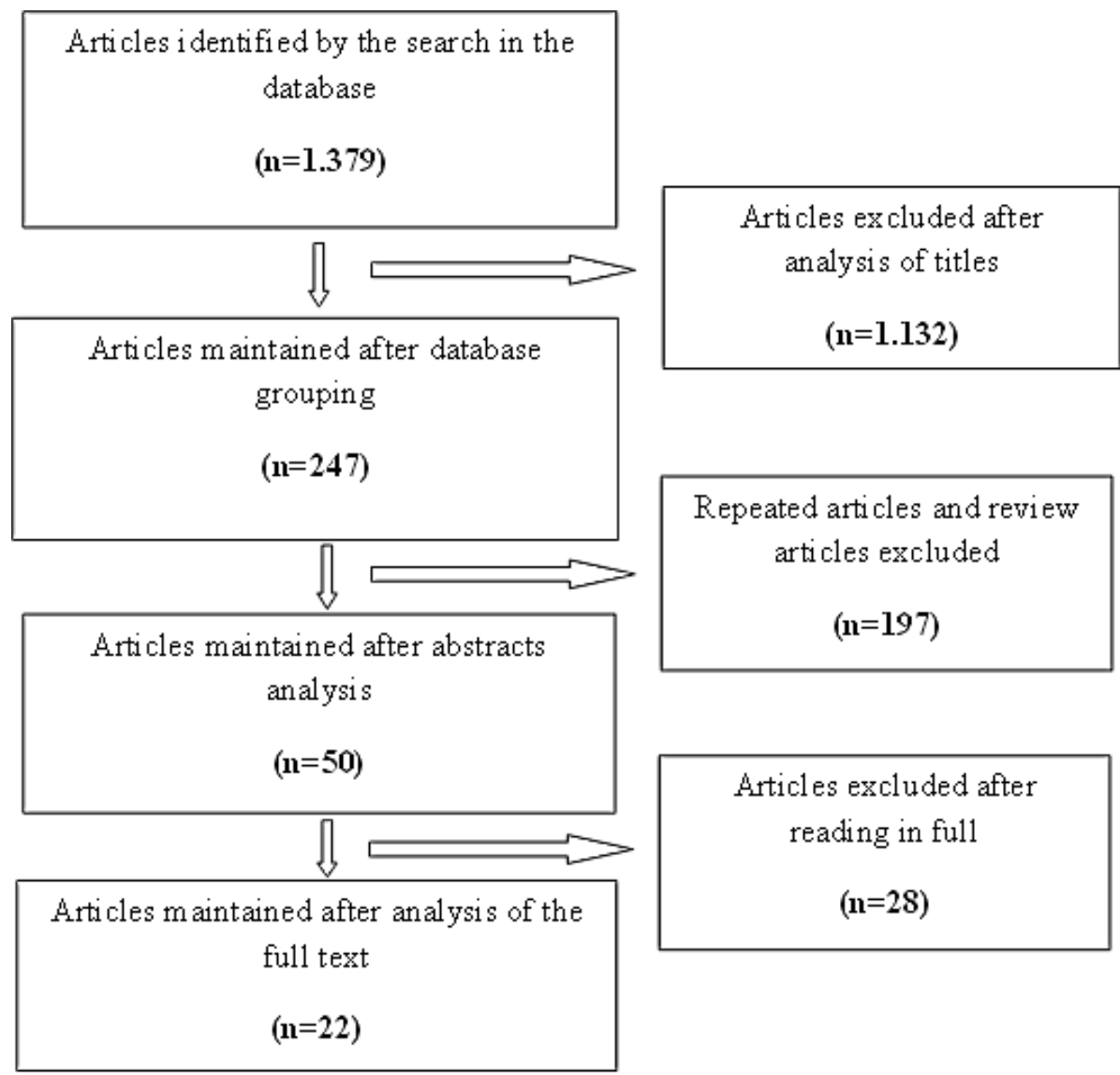

Tabela 1. Evaluation of the articles regarding the type of test performed.

\begin{tabular}{cc}
\hline Typeoftestperformed & Numberofarticles \\
\hline Pre-clinical: & 02 \\
In vivo & 18 \\
In vitro & 02 \\
In vivo and In vitro & 0 \\
Clinicaltest & $\mathbf{2 2}$ \\
\hline Total
\end{tabular}


Table 2. Summary of articles elected.

\begin{tabular}{|c|c|c|c|c|c|}
\hline PART OF THE PLANT & SOLVENT EXTRACTOR & SAMPLE & TEST PERFORMED & RESULT / ACTION & REFERENCE \\
\hline Leaves & Hexane, Ethyl acetate and Methanol & In vitro & $\begin{array}{l}\text { Toxicity and antioxidante } \\
\text { activity }\end{array}$ & No toxic or antioxidant effect & Aarlandet al., 2015. \\
\hline Leaves & Methanol & In vitro & $\begin{array}{l}\text { Inhibitory activity for tumor } \\
\text { necrosis factor (TNF- } \alpha)\end{array}$ & Low inhibition of TNF- $\alpha$ & Batubaraet al., 2012. \\
\hline Leaves & $\begin{array}{l}\text { Hydrodistillation }(\mathrm{H} 2 \mathrm{O}) \text { to obtain essential } \\
\text { oils }\end{array}$ & In vitro & $\begin{array}{l}\text { Antioxidant and antimicrobial } \\
\text { activity }\end{array}$ & $\begin{array}{l}\text { Antioxidant and antibacterial } \\
\text { effect }\end{array}$ & Boligonet al., 2013. \\
\hline Leaves & Ethanol & In vitro & Antiparasiticactivity & $\begin{array}{l}\text { Cytotoxic effect against } \\
\text { Trypanosoma cruzi, } \\
\text { Leishmania infantum and } \\
\text { Leishmania brasiliensis }\end{array}$ & Calixto-Júnior, 2016. \\
\hline Stalk & Acetone, Hexane and Methanol & In vitro & $\begin{array}{l}\text { Antimicrobial and inhibitory } \\
\text { activity against cancer cells }\end{array}$ & Inhibition of cancer cell activity & Cates et al., 2013. \\
\hline Isolated Compound (Tyliroside) & Methanol & In vitro & $\begin{array}{l}\text { Antiproliferative activity on } \\
\text { cancer cells }\end{array}$ & $\begin{array}{l}\text { Antiproliferative effect on } \\
\text { cancer cells }\end{array}$ & Da'Iet al., 2016. \\
\hline Leaves & Aqueous and Ethanol & In vitro & $\begin{array}{l}\text { Inhibitory test on pancreatic } \\
\text { lipase }\end{array}$ & $\begin{array}{l}\text { Potent inhibition on pancreatic } \\
\text { lipase }\end{array}$ & Iswantiniet al., 2011. \\
\hline Leaves & Ethanol & In vitro e in vivo & $\begin{array}{l}\text { Identification of antiglycemic } \\
\text { compounds }\end{array}$ & $\begin{array}{l}\text { Presence of glucocinin and } \\
\text { probable effect against diabetes } \\
\text { mellitus }\end{array}$ & Laguna-Hernandez et al., 2017. \\
\hline Barks & Ethyl Acetate and Methanol & In vitro & Antimicrobialactivity & Antimicrobial effect & $\begin{array}{l}\text { Luna-Cazares \& González- } \\
\text { Esquinca, } 2017 .\end{array}$ \\
\hline Barks & Hydroalcoholic & In vitro & Anti-inflammatoryactivity & Anti-inflammatory effect & Maldini et al, 2013. \\
\hline Leaves & Hydroalcoholic & In vitro & $\begin{array}{l}\text { Inhibitoryactivity in } \\
\text { adipogenesis }\end{array}$ & $\begin{array}{l}\text { Inhibitory effect on } \\
\text { adipogenesis }\end{array}$ & Hidayat et al., 2015. \\
\hline Barks and leaves & Ethanol & In vitro & $\begin{array}{l}\text { Antioxidant, anticholinesterase } \\
\text { and antifungal activity }\end{array}$ & $\begin{array}{l}\text { Antioxidant effect, } \\
\text { anticholinesterase and low } \\
\text { antifungal effect }\end{array}$ & Morais, S. M. et al., 2017. \\
\hline Leaves & $\begin{array}{l}\text { Ethanol, Hexane, Ethyl Acetate and } \\
\text { Chloroform }\end{array}$ & In vivo & $\begin{array}{l}\text { Proliferation and differentiation } \\
\text { of preadipocytes }\end{array}$ & $\begin{array}{l}\text { Inhibitory effect on } \\
\text { proliferation and differentiation } \\
\text { of pre-adipocytes }\end{array}$ & Nuri et al., 2016. \\
\hline Leaves and fruits & Aqueous & In vitro & Phytochemical screening & $\begin{array}{l}\text { Active compounds have been } \\
\text { identified }\end{array}$ & Patil \& Biradar, 2013. \\
\hline Leaves & Dragsteam for oil & In vitro & Phytochemicalscreening & $\begin{array}{l}\text { Active compounds have been } \\
\text { identified }\end{array}$ & Peláez\& Rodríguez, 2016. \\
\hline
\end{tabular}




\begin{tabular}{|c|c|c|c|c|c|}
\hline PART OF THE PLANT & SOLVENT EXTRACTOR & SAMPLE & TEST PERFORMED & RESULT / ACTION & REFERENCE \\
\hline Leaves & Hexane, Dichloromethane and Methanol & In vitro & $\begin{array}{l}\text { Antifungal and antibacterial } \\
\text { activity }\end{array}$ & $\begin{array}{l}\text { Antifungal and antibacterial } \\
\text { effect }\end{array}$ & Salcedoet al., 2014. \\
\hline Leaves & Alcoholic & In vivo & Curing wound healing activity & Reepithelization effect & Senthil et al., 2011. \\
\hline Drypowderplant & Methanol & In vitro & Antifungal activity & Antifungal effect & $\begin{array}{l}\text { Shekhawat \& Vijayvergia, } \\
2010 .\end{array}$ \\
\hline Drypowderplant & Alcoholic & In vitro & Anti-helminth activity & Anti-helminthic effect & $\begin{array}{l}\text { Shekhawat \& Vijayvergia, } \\
2011 .\end{array}$ \\
\hline Leaves, flowers, barks and fruits & Aqueous & In vitro & Phytochemical screening & $\begin{array}{l}\text { Active compounds have been } \\
\text { identified }\end{array}$ & Situmorang et al., 2015. \\
\hline Leaves & Ethanolic & In vitro e in vivo & $\begin{array}{l}\text { Activity on the accumulation of } \\
\text { lipids }\end{array}$ & $\begin{array}{l}\text { Inhibitory effect on the } \\
\text { accumulation of lipids }\end{array}$ & $\begin{array}{l}\text { Sulistiyani, Purwakusumah \& } \\
\text { Andrianto, } 2017 .\end{array}$ \\
\hline Barks & Ethanolic & In vitro & $\begin{array}{l}\text { Antifungal, antibacterial and } \\
\text { toxicity test }\end{array}$ & $\begin{array}{l}\text { Antifungal, antibacterial and no } \\
\text { toxic effect }\end{array}$ & Violante et al., 2012. \\
\hline
\end{tabular}


Table 3. Phytochemical analyzes described in the articles analyzed on Guazuma ulmifolia Lamark.

\begin{tabular}{|c|c|c|c|c|c|c|c|}
\hline Extraction & \multicolumn{2}{|c|}{ Methanol } & \multirow{2}{*}{$\begin{array}{c}\text { EthylAcetate } \\
\text { Luna_Cazares } \\
\text { et al., } 2017\end{array}$} & \multicolumn{2}{|l|}{$\mathrm{H}_{2} \mathrm{O}$} & \multirow{2}{*}{$\begin{array}{c}\text { Dragsteam } \\
\text { Peláez e } \\
\text { Rodríguez et } \\
\text { al., } 2016\end{array}$} & \multirow{2}{*}{$\begin{array}{c}\text { Ethanol } \\
\begin{array}{c}\text { Iswantini et } \\
\text { al., } 2011\end{array}\end{array}$} \\
\hline 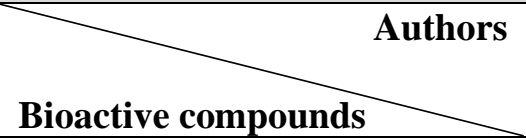 & $\begin{array}{l}\text { Batubara et } \\
\text { al., } 2012\end{array}$ & $\begin{array}{c}\text { Luna-Cazares et } \\
\text { al., } 2017\end{array}$ & & $\begin{array}{l}\text { Patil e Biradar et } \\
\text { al., } 2013\end{array}$ & $\begin{array}{l}\text { Iswantini } \\
\text { et al., } \\
2011\end{array}$ & & \\
\hline Flavonoids & $+^{\mathrm{A}}$ & $+^{\mathrm{C}}$ & $+^{\mathrm{C}}$ & $+^{\mathrm{A}, \mathrm{B}}$ & $+^{\mathrm{A}}$ & - & $+^{\mathrm{A}}$ \\
\hline Total Phenolic & $t^{\mathrm{A}}$ & $+^{\mathrm{C}}$ & $+^{\mathrm{C}}$ & - & - & - & - \\
\hline Alkaloids & - & $+^{\mathrm{C}}$ & $+^{\mathrm{C}}$ & $t^{\mathrm{A}, \mathrm{B}}$ & - & - & - \\
\hline Glucosides & - & $+^{\mathrm{C}}$ & $+^{\mathrm{C}}$ & - & - & - & - \\
\hline Saponin & - & $+^{\mathrm{C}}$ & $+^{\mathrm{C}}$ & $+^{\mathrm{A}, \mathrm{B}}$ & $+^{\mathrm{A}}$ & - & $+^{\mathrm{A}}$ \\
\hline Terpenes-steroids & - & $+^{\mathrm{C}}$ & $+^{\mathrm{C}}$ & - & - & - & - \\
\hline Tannins & - & - & - & $t^{\mathrm{A}, \mathrm{B}}$ & $+^{\mathrm{A}}$ & - & $+^{\mathrm{A}}$ \\
\hline Terpenoids & - & - & - & $+^{\mathrm{A}, \mathrm{B}}$ & - & - & - \\
\hline Cardiacglycoside & - & - & - & $t^{\mathrm{A}, \mathrm{B}}$ & - & - & - \\
\hline Steroids & - & - & - & $t^{\mathrm{A}, \mathrm{B}}$ & - & - & $+^{\mathrm{A}}$ \\
\hline Monoterpenes & - & - & - & - & - & $+^{\mathrm{A}}$ & - \\
\hline Sesquiterpenes & - & - & - & - & - & $+^{\mathrm{A}}$ & - \\
\hline Aliphatic Hydrocarbons & - & - & - & - & - & $t^{\mathrm{A}}$ & - \\
\hline
\end{tabular}


In vitro assays, G. ulmifolia presented the most antimicrobial effect, suggesting that the presence of some chemical compounds such as flavonoids and tannins in the plant are capable of promoting the inhibition of microorganisms (VIOLANTE et al. 2012; BOLIGON et al., 2013, CATES et al., 2013, PATIL e BIRADAR, 2013). According to Shekhawat (2011), Salcedo et al. (2014), Karthika et al. (2017), Luna-Cazares e González-Esquinca (2017), the antibacterial action of natural extracts are an important source for the discovery of active molecules. Pharmacological effects of flavonoids may be responsible for the antioxidant, anticancer and antifungal actions evidenced (SHEKHAWAT e VIJAYVERGIA, 2010; BOLIGON et al., 2013, CATES et al., 2013, PATIL e BIRADAR, 2013, SALCEDO et al., 2014; DA'I et al., 2016; MORAIS et al., 2017; KARTHIKA et al., 2017).

In in vivo studies, LagunaHernandez et al. (2017) demonstrated that Guazuma has antihyperglycemic action, proven by histochemical analysis of the pancreas of mice. Nuri et al. (2016) detected in their assays that the ethanolic extracts from Guazuma leaves inhibit the proliferation of preadipocytes in Wistar rats. According to Sulistiyani et al. (2017) the ethanolic extract showed inhibitory activity in the accumulation of lipids under study with Caenorhabditis elegans (nematode). Another study using a chemically induced wound model in rats showed that leaf alcohol extract is effective in re-epithelialization and wound healing in topical use (SENTHIL et al., 2011).

Therefore, research with humans through randomized and methodologically well-conducted clinical trials should be performed to evaluate their efficacy so that they can be safely indicated in clinical practice. In addition, we can cite the low amount of pharmacokinetic, pharmacodynamic, toxicological and in vivo studies.

\section{FINAL CONSIDERATIONS}

Guazuma ulmifolia presents, in addition to popular reports of use, studies that can subsidize and justify its use in therapeutics, and as a promising source of new compounds of pharmacological interest. The main evidences of pharmacological effects related to the use of this medicinal plant were: i) antimicrobial effect; ii) antioxidant effect; iii) anticancer action and iv) antihyperglycemic. However, in vivo studies and clinical trials are necessary in order to assure its safety of use and to attest its therapeutic effects.

\section{ACKNOWLEDGMENTS}

The authors thank the Federal University of Tocantins and $\mathrm{CNPq}$ for supporting this research.

All authors declare that there is no potential conflict of interest regarding this article.

\section{REFERENCES}


AARLAND, R. C.; PERALTA-GÓMEZ, S.; SANCHÉZ, C. M.; PARRABUSTAMANTE, F.; VILLAHERNÁNDEZ, J. M.; LEÓN-SÁNCHEZ, F. D.; PÉREZ-FLORES, L. J.; RIVERACABRERA, F.; MENDOZA-ESPINOZA, J. A. A pharmacological and phytochemical study of medicinal plants used in Mexican folk medicine. Indian Journal of Traditional Knowledge.v.14, n.4, p.550$557,2015$.

ANDRADE-CETTO, A.; HEINRICH, M. Mexican plants with hypoglycaemic effect used in the treatment of diabetes.Journal ofEthnopharmacology.v.99, n.3, p. 325348, 2005.

BANDYOPADHYAY,U.;BISWAS,K.;S ENGUPTA,A.;MOITRA， P.;DUTTA, P.;SARKAR,D.; DEBNATH, P.;GANGULY, C. K.; BANERJEE, R. K. 2004. Clinical studies on the effect of Neem (Azadirachtaindica) bark extract on gastric secretion and gastroduodenal ulcer. Life Sciences.v.75, n.24, p.28672878,2004 .

BATUBARA,I.; KOTSUKA, S.; YAMAUCHI, K.; KUSPRADINI, H.; MITSUNAGA, T.; DARUSMAN, L. K.TNF- $\alpha$ ProductionInhibitory Activity, Phenolic, Flavonoid and Tannin Contents of Selected Indonesian Medicinal
Plants.ResearchJournal of Medicinal Plant.v.6, n.6, p.406-415, 2012.

BERENGER, B.; TRABADELA, C.; SÁNCHEZ-FIDALGO, S.; AQUÍLEZ, A.; MINÕ, P.; DE LA PUERTA, R.; MARTÍN-CALERO, M. J.The aerial parts of Guazuma ulmifolia Lam. protect against NSAID-induced gastric lesions. Journal of Ethnopharmacology.v.114, n.2, p.153 $160,2007$.

BOligON, A. A.; FELTRIN, A. C.; ATHAYDE, M. L. Determination of chemical composition, antioxidant and antimicrobial properties of Guzumaulmifoliaessential oil.American Journal of Essential Oils and Natural

Products.v.1, n.1, p. 23-27,2013.

CALIXTO, J. B. Efficacy, safety, quality control, marketing and regulatory guidelines for herbal medicines (phytotherapeutic agents).BrazilianJournalandBiologicalR esearch.v.33, n.2, p.179-189,2000.

CALIXTO-JUNIOR, J. T.; MORAES, S. M.; GOMEZ, C. V.; MOLAS, C. C.; ROLON, M.; BOLIGON, A. A.; ATHAYDE, M. L.; OLIVEIRA, C. D. M.; TINTINO, S. R.; COUTINHO, H. D. M.Phenolic composition and antiparasitic activity of plants from the Brazilian Northeast

“Cerrado".Saudi 
JournalofBiologicalSciences.v.23, n.3, p. 434-440, 2016.

CARVALHO, P. E. R. Espécies arbóreas brasileiras.Embrapa Informação

Tecnológica, Brasília, DF. 627, p.,2007.

CATES, R. G.; PRESTWICH, B.; INNES, A.; ROWE, M.; STANLEY, M.; WILLIAMS, S.; THOMPSON, A.; MCDONALD, S.; CATES, S.; SHRESTHA, G.; SORIA, J. A. F.; ESPINOZA, L. V.; ARDÓN, C.; GALVEZ, B.; DÍAZ, M. R.; CORONADO, F. S.; GARCÍA，J. R.;ARBIZÚ，D. A.; MARTINEZ, J. V. Evaluation of the activity of Guatemalan medicinal plants against cancer cell lines and microbes.Journal Medicinal ofPlantsResearch.v.7, n.35, p.2616$2627,2013$.

COPETTI, F. B. e GRIBELER, S. A.Análise da adequação da rotulagem de medicamentos fitoterápicos. Infarma.v.17, 2005.

CRUZ, G. L.Dicionário de Plantas Úteis do Brasil. $5^{\text {a }}$ Ed., Editora Bertrand, Rio de Janeiro,Brasil. 995.

DA'I, M.; WIKANTYASNING, E. R.; WAHYUNI, A. S.; KUSUMAWATI, I. T. D.; SAIFUDIN, A.; SUHENDI, A.Antiproliferative properties of tiliroside from GuazumaulmifoliaLamk on T47D and MCF7 cancer cell lines. National Journal of Physiology. Pharmacy and Pharmacology.v.6, n.6, p. 627-633, 2016.

GUÁZUMA. Plantas Medicinales. Edição especial do guía México, México. In: CARVALHO, P. E. R., 2007. Espécies arbóreas brasileiras.Embrapa Informação Tecnológica, Brasília, DF. 627 p., 2001.

HEINRICH, M.Ethnobotany and natural products: the search for new molecules, new treatments of old diseases or a better understanding of indigenous cultures? Current Topics in Medical Chemistry.v.3, n;2, p.141-154,2003.

HIDAYAT, M.; SOENG, S.; PRAHASTUTI, S.; ERAWIJANTARI, P. P.; WIDOWATI, W.; Inhibitory potential of ethanol extract of Detam 1 Soybean (Glycine max) seed and JatiBelanda (Guazumaulmifolia) leaves on adipogenesis and obesity models in 3T3-L1 Cell Line. Journal of Scientific Research \& Reports. v.6, n.4,p.304-312,2015.

ISWANTINI， D.; SILITONGA， R. F.; MARTATILOFA, E.; DARUSMAN, L. K.Zingibercassumunar,

Guazumaulmifolia, and Murrayapaniculataextracts as antiobesity: In Vitro inhibitory effect on pancreatic lipase activity. 
HAYATIJournalofBiosciences.v.18,n.1,p .6-10,2011.

JBRJ, GuazumainFlora do Brasil 2020 em construção. Jardim Botânico do Rio de Janeiro. 2017. Disponível em: <http://reflora.jbrj.gov.br/reflora/floradobr asil/FB9065>. Access: October 30, 2017.

KARTHIKA， V.; ARUMUGAM， A.; GOPINATH, K.; KALEESWARRAN, P.; GOVINDARAJAN, M.; ALHARBI, N. S.; KADAIKUNNAN, S.; KHALED, J. M.; BENELLI, G.Guazumaulmifolia barksynthesized $\mathrm{Ag}, \mathrm{Au}$ and $\mathrm{Ag} / \mathrm{Au}$ alloy nanoparticles: Photocatalytic potential, DNA/protein interactions, anticancer activity and toxicity against 14 species of microbial pathogens. Journal of Photochemistry \& Photobiology, B: Biology.v,167, p.189-199,2017.

LAGUNA-HERNANDEZ， G.; RIOZAMORANO, C. A.; MENESESOCHOA, I. G.; RECHU-FRANCO, A. E.Histochemistry and immunolocalisation of glucokinin in antidiabetic plants used in traditional Mexican medicine.EuropeanJournal of Histochemistry.v.61, n.2, p.125 $134,2017$.

LUNA-CAZÁRES, L. M.; e GONZÁLEZESQUINCA, A. R. Metabolitos secundarios y actividad antibacteriana de
GuazumaulmifoliaLam. (Caulote) endos etapas fenológicas. Lancandonia. v.1, n.1, p.37-43,2017.

MALDINI, M.; DI MICCO, S.; MONTORO, P.; DARRA, E.; MARIOTTO, S.; BIFULCO, G.; PIZZA, C.; PIACENTE, S.Flavanocoumarins fromGuazumaulmifoliabarkandevaluationo ftheiraffinity for $\quad$ STAT1. Phytochemistry.v.86, p.64-71,2013.

MORAIS, S.M.; CALIXTO-JÚNIOR, J. T.; RIBEIRO, L.M.; SOUSA, H. A.; SILVA,A.A. $\quad$ S.;FIGUEIREDO,F. G.; MATIAS,E.F. F.; BOLIGON, A. A.; ATHAYDE,M.L.; MORAIS-BRAGA, M.F.B.; COUTINHO,

H.D.M.Phenolicantibiotic-

modulatingantifungalactivitiesofGuazuma ulmifoliaLam. (Malvaceae) ethanol extract South African. Journal of Botany. v.110, p.251-257,2017.

NURI, S. e PRAYOGO,B.Inhibitory effect of non-polar and semi-polar fractions of ethanolic extract of GuazumaulmifoliaLamk. leaves on rat preadipocytes proliferation and differentiation. Proceeding ICMHS.p.6669,2016.

PATIL, J. U. e BIRADAR, S. D.Pharmacognostic study of Guazumaulmifolia.InternationalResearch 
JournalofPharmacy.v.4, n.4, p.130131,2013 .

PELÁEZ, J. M.; RODRÍGUEZ, J. G.Composición Química del Aceite Esencial de Hojas de Guazumaulmifolia(Malvaceae). Scientia et Technica.v.21, n.3,p.260-272,2016.

SALCEDO, H. E. R.; VIRGENCALLEROS, G.; VARGAS-RADILLO, J. J.; SALCEDO-PEREZ, E.; BARRRIENTOS-RAMIREZ, L. Actividad antimicrobiana in vitro de extractos de hoja de GuazumaulmifoliaLam. contrafitopatógenos. Revista Mexicana de Ciencias Forestales.v.6, n.27,p.114124,2014

SENTHIL, A. P.; KUMAR, A.; MANASA, M.; KUMAR, K. A.; SRAVANTHI, K.;DEEPA, D.Wound healing activity of alcoholic extract of "Guazumaulmifolia" leaves on albino wistar rats. International Journal of Pharma and Bio Sciences. v.02,n.4,p.34-38,2011.

SHEKHAWAT, N. e VIJAYVERGIA, R. Evaluation of antimicrobial potential of some medicinal plants against plant and human pathogens.Journal of Pharmacy Research. v.3, n.4,p.700-702,2010.

SHEKHAWAT, N. e VIJAYVERGIA, R. Anthelmintic activity of extracts of some medicinal plants.International Journal of Computational Science and Mathematics.v.3, n.2,p.183-187,2011.

SITUMORANG, R. O. P.; HARIANJA, A. H.; SILALAHI, J.Karo's local wisdom: the use of woody plants for traditional diabetic medicines. Indonesian Journal of Forestry Research.v.2, n.2,p.121131,2015 .

SOUZA, V. C. e LORENZI, H.Botânica Sistemática.Nova Odessa: Instituto Plantarum. 704 p., 2008.

SULISTIYANI, P. E. P. e ANDRIANTO, D.In vivo inhibition of lipid accumulation in Caenorhabditselegans.Earth and environmental Science.v.58, p.1-7,2017.

VEIGA JUNIOR, V. F.; PINTO, A. C.;MACIEL, M. A. M.Plantas medicinais: cura segura?Química nova.v.28, n.3, p.519-528,2005.

VIOLANTE, I. M. P.; HAMERSKI, L.; GARCEZ, W. S.; BATISTA, A. L.; CHANG, M. R.; POTT, V. J. GARCEZ, F. R.Atividade antimicrobiana de algumas plantas medicinais do cerrado da Região Centro-Oeste do Brasil. BrazilianJournalofMicrobiology. v.43, n.4, p.1302-1308, 2011. 